\title{
Inhibition of nuclear factor- $\kappa B$ activity by small interfering RNA in esophageal squamous cell carcinoma cell lines
}

\author{
TOMOKO HATATA $^{1}$, KATSUMI HIGAKI $^{2}$, EIJI NANBA ${ }^{2}$, SHIGERU TATEBE $^{1}$ and MASAHIDE IKEGUCHI ${ }^{1}$ \\ ${ }^{1}$ Division of Surgical Oncology, Department of Surgery, Faculty of Medicine, and ${ }^{2}$ Division of Functional \\ Genomics, Research Center for Bioscience and Technology, Tottori University, Yonago, Japan
}

Received February 7, 2011; Accepted April 15, 2011

DOI: $10.3892 /$ or.2011.1313

\begin{abstract}
Chemotherapy with 5-fluorouracil (5-FU) is commonly used in combination therapy for esophageal squamous cell carcinoma (ESCC), but its efficacy is limited in certain patients. Recent studies suggest that constitutive activation of nuclear factor $-\kappa \mathrm{B}(\mathrm{NF}-\kappa \mathrm{B})$ has a critical role in tumorigenesis and is associated with poor prognosis and resistance to chemoradiation therapy in many types of human cancers. In the present study, we evaluated the effect of small interfering RNA targeting NF- $\kappa \mathrm{B}$ (NF- $\kappa \mathrm{B}$ siRNA) combined with 5-FU on the proliferation of two cell lines of cultured ESSCs. Immunofluorescence and immunoblot analyses revealed that the NF- $\kappa \mathrm{B}$ protein was localized mostly in the cytoplasm of ESCCs. When cultured ESCCs were exposed to tumor necrosis factor- $\alpha, \mathrm{NF}-\kappa \mathrm{B}$ was transferred to the nucleus and activated. ESCCs with activated $\mathrm{NF}-\kappa \mathrm{B}$ had poor sensitivity to $5-\mathrm{FU}$. When cells were transfected with $\mathrm{NF}-\kappa \mathrm{B}$ siRNA, the levels of $N F-\kappa B$ protein were significantly decreased in the cytoplasm and the nucleus. Transcriptional activity of NF- $\kappa \mathrm{B}$ was significantly suppressed in cells treated with 5-FU and NF- $\mathrm{BB}$ siRNA compared to cells treated with 5-FU alone. 5-FU consistently suppressed proliferation of ESCCs in a dose-dependent manner, and this effect was significantly enhanced when combined with NF- $\kappa B$ siRNA. These results suggest that combination therapy of 5-FU with
\end{abstract}

Correspondence to: Dr Katsumi Higaki, Division of Functional Genomics, Research Center for Bioscience and Technology, Tottori University, 86 Nishi-cho, Yonago 683-8503, Japan

E-mail:kh4060@med.tottori-u.ac.jp

Dr Masahide Ikeguchi, Division of Surgical Oncology, Department of Surgery, Faculty of Medicine, Tottori University, 36-1 Nishi-cho, Yonago 683-8504, Japan

E-mail:masaike@med.tottori-u.ac.jp

Abbreviations: ESCC, esophageal squamous cell carcinoma; 5-FU, 5-fluorouracil; NF- $\kappa B$, nuclear factor- $\kappa \mathrm{B}$; siRNA, small interfering RNA; TNF $\alpha$, tumor necrosis factor $\alpha$

Key words: esophageal squamous cell carcinoma, 5-fluorouracil, nuclear factor- $\kappa \mathrm{B}$, siRNA
$\mathrm{NF}-\kappa \mathrm{B}$ siRNA may provide a new therapeutic option for ESCC.

\section{Introduction}

Esophageal squamous cell carcinoma (ESCC) remains a disease with a poor prognosis. The overall 5-year survival rate is approximately $50 \%$ (1), a figure that has recently been improved by surgical developments and perioperative management, chemotherapy and radiation therapy. 5-Fluorouracil (5-FU) is commonly used in combination therapy for esophageal cancer. It is converted to the active metabolite 5-fluoroxyuridine monophosphate (F-UMP); F-UMP incorporates into RNA and inhibits RNA processing, thereby inhibiting cell growth. 5-FU is also metabolized to 5-5-fluoro2'-deoxyuridine-5'-O-monophosphate (F-dUMP); F-dUMP inhibits thymidylate synthase, resulting in thymidine triphosphate depletion. This causes DNA damage during DNA synthesis, resulting in the induction of apoptosis $(2,3)$. However, the sensitivity to 5-FU is different in each patient, and many esophageal cancers are inherently or developmentally resistant to chemotherapy with 5-FU. Thus, effective methods to suppress this resistance are being explored.

Nuclear factor- $\kappa \mathrm{B}(\mathrm{NF}-\kappa \mathrm{B})$ belongs to a family of inducible transcription factors that regulate the gene expression involved in immune and inflammatory responses. $N F-\kappa B$ is also involved in cell proliferation and anti-apoptotic pathways (4-6). NF- $\mathrm{NB}$ is expressed in the cytoplasm of unstimulated cells and is comprised of a heterotrimer of p65, p50 and an inhibitor protein, I $\kappa$ B. When cells are treated with certain stimuli, such as cytokines, NF- $\kappa \mathrm{B}$ is activated by phosphorylation and ubiquitination of $\mathrm{I} \kappa \mathrm{B}$. The degradation of $\mathrm{I} \kappa \mathrm{B}$ results in the translocation of the $N F-\kappa B$ heterodimer $(p 65-$ p50) from the cytoplasm to the nucleus, where it activates the expression of specific genes $(4,6,7)$. Several lines of evidence show that the activation of $N F-\kappa B$ is also related to inducible chemoresistance (8). Therefore, regulation of NF- $\kappa \mathrm{B}$ expression is thought to be extremely important for enhancing the efficacy of chemotherapeutic agents in the treatment of cancer patients.

Previously, we reported that NF- $\kappa \mathrm{B}$ siRNA with chemotherapy successfully prolongs survival in a xenograft model with peritoneal metastasis of gastric cancer (9). This result prompted us to test whether NF- $\mathrm{B}$ siRNA administration is 
also effective for ESCC. In this study, we investigated the efficacy of 5-FU and NF- $\mathrm{KB}$ siRNA on two ESCC cell lines and the effect of tumor necrosis factor- $\alpha$ (TNF $\alpha$ ) on NF- $\mathrm{kB}$.

\section{Materials and methods}

Cell culture. The human esophageal cancer cell lines, TE4 and TE8, were obtained from Riken BioResource Center (National Bio-Resource Project of the MEXT, Tsukuba, Japan). They were routinely cultured in RPMI-1640 (Wako, Tokyo, Japan) supplemented with 10\% FBS (Hyclone Lab, Waltham, MA, USA) at $37^{\circ} \mathrm{C}$ in a $5 \% \mathrm{CO}_{2}$ atmosphere. Histology of TE4 was that of a highly differentiated squamous cell carcinoma, and that of TE8 was a moderately differentiated squamous cell carcinoma. 5-FU (Wako) treatment was carried out by replacing the culture medium with medium containing indicated concentrations of 5-FU, and cells were incubated for $24 \mathrm{~h}$. For TNF $\alpha$ treatment (Wako), cells were cultured in the medium with $\mathrm{TNF} \alpha(0.05 \mu \mathrm{g} / \mathrm{ml})$ for $12 \mathrm{~h}$.

Antibodies and siRNA. Rabbit polyclonal antibodies against NF- $\kappa B$ p65 (sc-109) and $\beta$-tubulin (sc-9104) and NF- $\kappa B$ siRNA (sc-29410) were purchased from Santa Cruz Biotechnology (Santa Cruz, CA, USA). Mouse monoclonal antibody to lamin A/C was purchased from Cell Signaling Technology (Danvers, MA, USA).

siRNA transfection. Transfection of siRNA was performed using Lipofectamine RNAiMAX (Invitrogen, Carlsbad, CA, USA) according to the manufacturer's protocol. Briefly, cells were plated in a $35-\mathrm{mm}$ dish to achieve a confluency of $30-50 \%$ in media containing $10 \%$ FBS and a mixture of NF- $\kappa$ B p65 siRNA (sc-29410, Santa Cruz) and Lipofectamine RNAiMAX. After incubation for $24 \mathrm{~h}$, cells were analyzed or collected for the following assays.

Immunofluorescence staining. All procedures were carried out at room temperature. Cells on coverslips were fixed with $3.7 \%$ formalin in phosphate-buffered saline (PBS) for $30 \mathrm{~min}$, permeabilized with $0.1 \%$ Triton X-100 in PBS for 15 min and blocked with $1 \%$ bovine serum albumin (BSA) in PBS for $1 \mathrm{~h}$. Cells were then incubated with the anti-NF- $\kappa$ B antibody (diluted to 1:100 in 0.1\% BSA in PBS) for $1 \mathrm{~h}$, followed by incubation with Alexa Fluor 488-conjugated anti-rabbit IgG (Invitrogen) for $1 \mathrm{~h}$. Fluorescence images were obtained using confocal microscopy (Leica TCS-SP2, Wetzler, Germany).

Western blot analysis. Cytoplasmic and the nuclear lysates were separately extracted using a ProteoExtract Subcellular Proteome Extraction Kit (Calbiochem, Darmstadt, Germany), and protein concentrations were determined with a Protein Assay Rapid Kit (Wako). Cell lysates (20 $\mu \mathrm{g}$ of cytoplasmic and $40 \mu \mathrm{g}$ of nucleic extracts) were separated by SDS-PAGE using $10 \%$ gels and transferred onto PVDF membranes. The membranes were blocked overnight at $4^{\circ} \mathrm{C}$ in Tris-buffered saline (TBS) containing $0.1 \%$ Tween- 20 and skimmed-milk and then incubated for $1 \mathrm{~h}$ with primary antibodies at the following dilutions: rabbit-anti-NF-kB (1:1000; Santa Cruz), rabbit anti-tubulin (1:1000; Santa Cruz), mouse anti-lamin A/C (1:2000; Cell Signaling Technology, Japan). Membranes were then incubated with HRP-conjugated anti-rabbit or anti-mouse IgG (1:5000; GE Healthcare, UK) for $1 \mathrm{~h}$. The antibody-antigen complex was detected using Amersham ECL plus reagents (GE Healthcare, UK), and images were obtained with an LAS-4000 IR image analyzer (Fujifilm, Japan).

BrdU assay. Cell proliferation was measured using a BrdU cell proliferation assay, an immunoassay for the quantitation of bromodeoxyuridine incorporation (Calbiochem). Briefly, cells in 96-well plates were incubated with BrdU for $5 \mathrm{~h}$. Cells that had incorporated BrdU were detected by incubation with anti-BrdU antibody and HRP-conjugated anti-mouse IgG. Absorbance was measured with a spectrophotometric plate reader Sunrise (Tecan Japan, Tokyo, Japan) at dual wavelengths of 450 and $540 \mathrm{~nm}$.

Apoptosis assay. Apoptosis of cultured cells was measured by detecting caspase activity using the carboxyfluorescein FLICA apoptosis detection kit (Immunochemistry Technologies, Bloomington, MN, USA). Cells in 24-well culture plates were treated with or without 5-FU or NF- $\mathrm{kB}$ siRNA overnight. After labeling with FLICA, cells were measured using a fluorescence plate reader Infinite F500 (Tecan Japan). Fluorescence of apoptotic cells induced by staurosporine was used as a positive control.

Luciferase assay. Transcriptional activity of NF- $\mathrm{B}$ was measured with a Ready-To-Glow Secreted Luciferase Reporter Assay Kit (Clontech, Mountain View, CA, USA). Briefly, cells in 6-well culture plates were transfected with the pNF- $\kappa \mathrm{B}-$ MetLuc2 reporter plasmid, which contains the $\mathrm{NF}-\kappa \mathrm{B}$ binding site in the promoter region of the Metridia luciferase reporter gene. After incubation for $24 \mathrm{~h}$, the activity of luciferase in the cell culture medium was measured as a representation of NF- $\mathrm{kB}$ activity using a luminometer Infinite F500 (Tecan Japan) and was expressed in arbitrary units. pEGFP-N1 (Clontech) was used as an internal transfection control for each experiment.

Statistical analysis. Statistical analysis was performed using Student's t-test to compare control and test groups (Statview J version 5.0; SAS Institute, Cary, NC, USA). The results are expressed as mean $\pm \mathrm{SD}$ except as otherwise stated. $\mathrm{P}<0.05$ was considered statistically significant.

\section{Results}

$N F-\kappa B$ siRNA efficiently suppresses $N F-\kappa B$ expression in ESCC cells. We first examined the cellular localization of $\mathrm{NF}-\mathrm{\kappa B}$ protein in TE4 and TE8 cells by immunofluorescence staining. Under normal culture conditions, NF- $\mathrm{KB}$ was detected mostly in the cytoplasm with low levels in the nucleus in both cell lines. When cells were transiently transfected with NF- $\mathrm{KB}$ siRNA, the level of NF- $\kappa B$ in the cytoplasm was significantly decreased (Fig. 1A). These results were confirmed by Western blot analysis (Fig. 1B and C).

Effect of 5-FU and NF- $\kappa B$ siRNA on ESCC cells. To assay the effect of 5-FU and NF- $\kappa B$ siRNA on the proliferation of TE4 
A

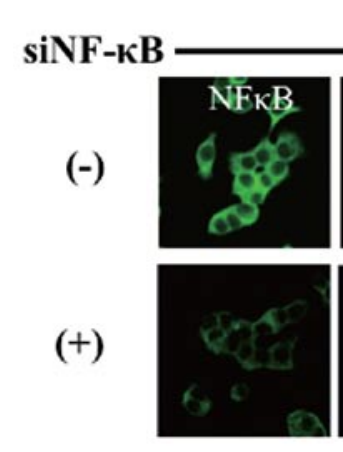

B

C
TE4
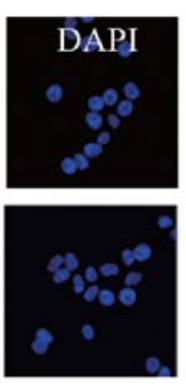
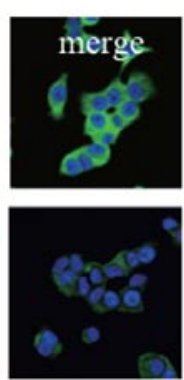

TE 4

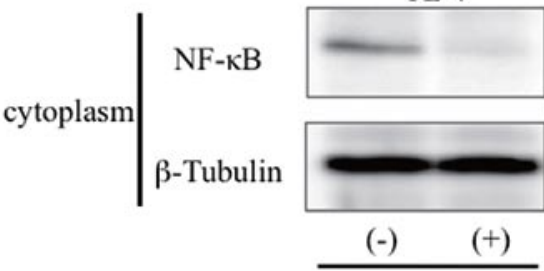

siNF-kB

TE 4

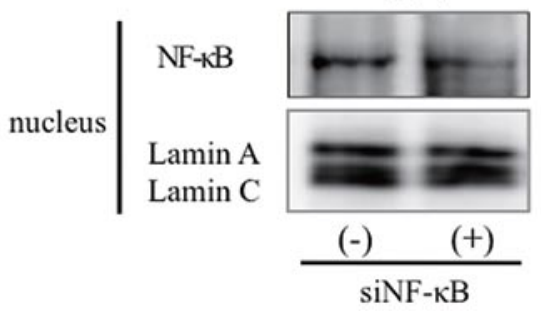

TE8
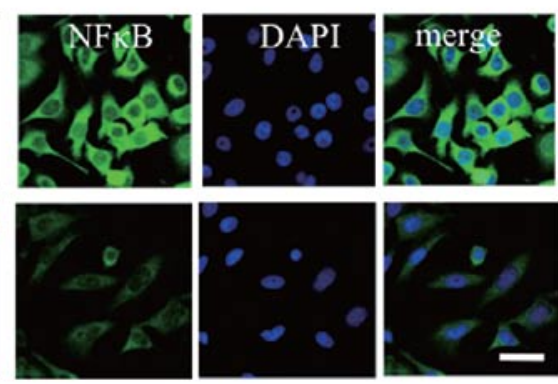

TE 8

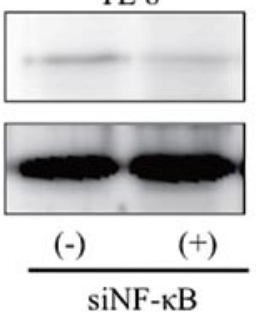

$65 \mathrm{kDa}$

$41 \mathrm{kDa}$

$50 \mathrm{kDa}$

$65 \mathrm{kDa}$

$55 \mathrm{kDa}$

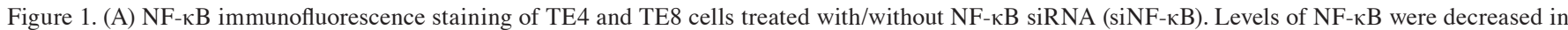

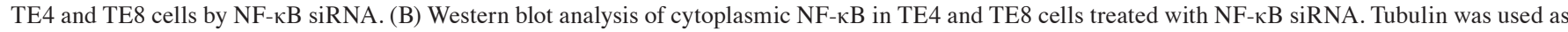
the loading control. (C) Western blot analysis of nuclear NF- $\kappa$ B in TE4 and TE8 cells treated with NF- $\mathrm{KB}$ siRNA. Lamin A and C were used as the loading control. Nuclear NF-kB was not detected in the TE8 cells.

and TE8 cells, we performed the BrdU incorporation assay. Treatment with 5-FU caused a dose-dependent suppression of BrdU incorporation in the two ESCC lines. At the same concentration of 5-FU, TE4 and TE8 cells transfected with $\mathrm{NF}-\kappa \mathrm{B}$ siRNA had less BrdU incorporation compared to cells transfected with control siRNA (Fig. 2A).

We measured caspase levels to evaluate the effect of 5-FU and NF- $\kappa \mathrm{B}$ siRNA on apoptosis of TE4 and TE8 cells. 5-FU induced apoptosis of TE4 and TE8 cells and NF- $\mathrm{KB}$ siRNA strongly induced apoptosis (Fig. 2B).

Effect of 5-FU and $N F-\kappa B$ siRNA on $N F-\kappa B$ transcriptional activity. We further examined the effects of 5-FU with $\mathrm{NF}-\kappa \mathrm{B}$ siRNA on the transcriptional activity of $N F-\kappa B$ in ESCC cells. To assess the transcriptional activity of $N F-\kappa B$, we transfected ESCC cells with pNF- $\kappa$ B-MetLuc2 and then measured the luciferase activity in the culture medium, with reference to the luciferase activity of untreated cells. 5-FU reduced $\mathrm{NF}-\kappa \mathrm{B}$ activity in TE4 and TE8 cells, and the combination of 5-FU and NF- $\mathrm{NB}$ siRNA strongly suppressed $\mathrm{NF}-\kappa \mathrm{B}$ activity in both cell lines compared with 5-FU treatment only. Also the combination of 5-FU and NF- $\kappa$ B siRNA produced a difference in activity between TE4 and TE8 cells (Fig. 3).
Effect of TNF $\alpha$ on TE4 and TE8 cells. TE4 and TE8 cells were treated with $\mathrm{TNF} \alpha$. TNF $\alpha$ induced the accumulation of $\mathrm{NF}-\kappa \mathrm{B}$ in the nucleus. 5-FU slightly decreased the levels of $\mathrm{NF}-\kappa \mathrm{B}$ in cells treated with TNF $\alpha$. A combination of 5-FU and $N F-\kappa B$ siRNA significantly decreased the levels of $N F-\kappa B$ in both the cytoplasm and nucleus of TNF $\alpha$-treated cells (Fig. 4A).

We measured the activity of NF- $\kappa$ B. TNF $\alpha$ strongly increased the activity of NF- $\mathrm{B}$. 5-FU only slightly suppressed $\mathrm{NF}-\kappa \mathrm{B}$ activity, but a combination of 5-FU and NF- $\kappa \mathrm{B}$ siRNA strongly suppressed it. The level of response to TNF $\alpha$ in TE4 and TE8 cells was different (Fig. 4B).

TNF $\alpha$ decreased the effect of 5-FU on TE4 and TE8 cells. Adding NF- $\kappa \mathrm{B}$ siRNA to TNF $\alpha$ - and 5-FU-treated TE4 and TE8 cells decreased the level of proliferation (Fig. 4C).

\section{Discussion}

Despite recent advances in surgical techniques and the combination of radiotherapy and chemotherapy treatments, the prognosis of many types of cancers remains poor due to advanced disease, metastasis and resistance to radiotherapy and chemotherapy (10). 5-FU is a commonly used treatment for ESCC and inhibits cell growth and induces apoptosis in 
A
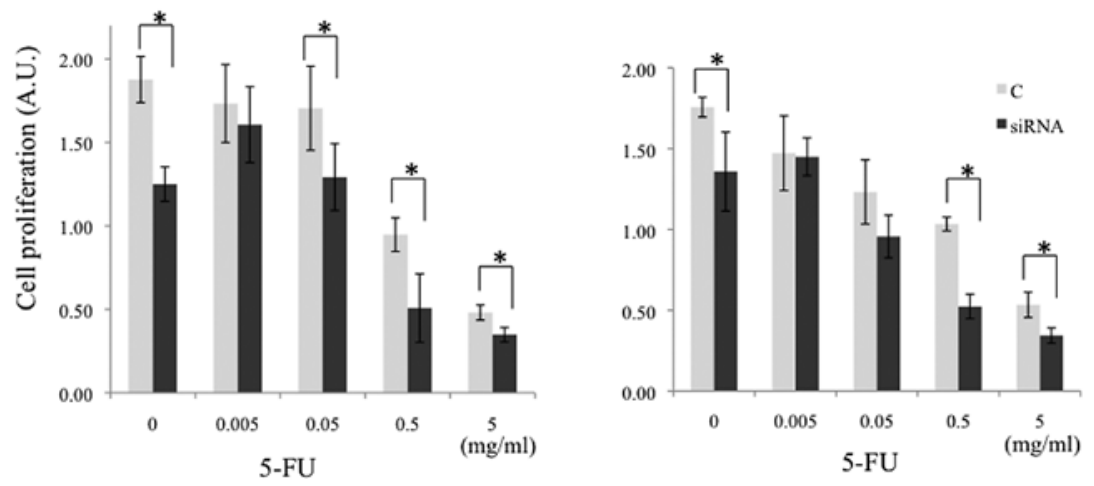

TE 4

TE 8

B
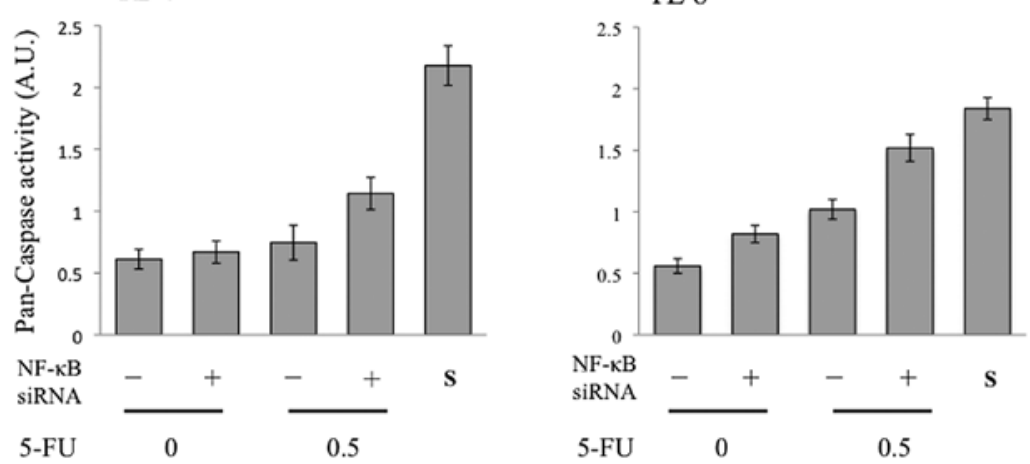

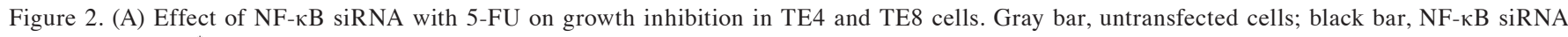
transfected cells. ${ }^{*} \mathrm{P}<0.05$ indicates that the viability of the transfected cells was significantly elevated compared to that of the untransfected cells. (B) Apoptosis assay showed that 5-FU and NF- $\mathrm{KB}$ siRNA induced apoptosis of TE4 and TE8 cells. S, staurosporine was used as a positive control.

TE4

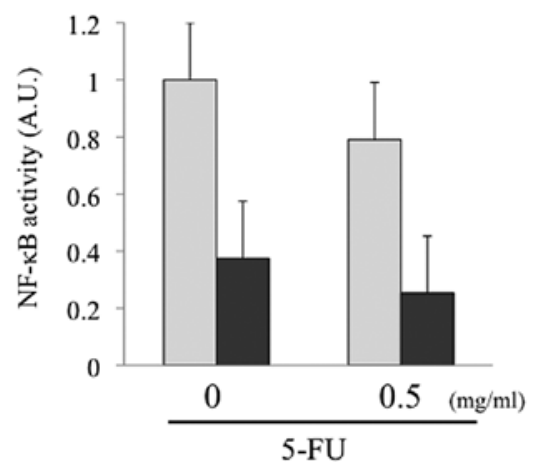

TE8

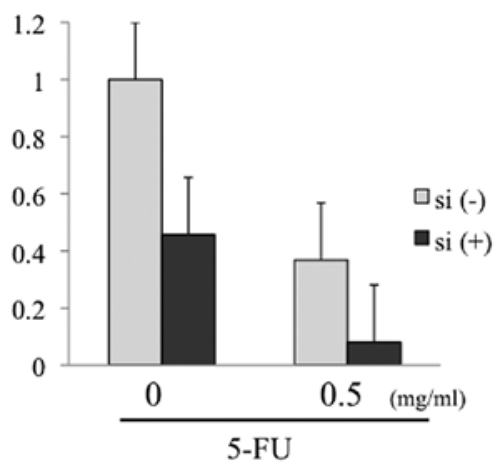

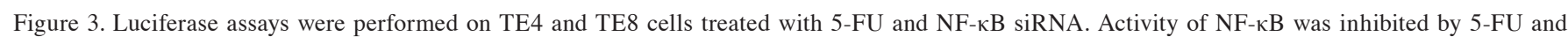
NF- $\mathrm{KB}$ siRNA. Relative activities of NF- $\mathrm{kB}$ are shown, with no treatment set at 1.0.

cancer cells (2). However, similar to other anticancer drugs, resistance is often observed (11). Moreover, the molecular mechanisms and the signaling pathways involved in ESCC chemoresistance are not yet clear.

Activation of NF- $\kappa \mathrm{B}$ signaling has a critical role in the development and progression of several types of cancer, including esophageal cancer (4). In our hospital, expression of NF- $\mathrm{KB}$ was detected in $61.5 \%$ of patients with ESCC, whose prognosis was relatively poor compared with patients who were negative for NF- $\mathrm{kB}$ expression (date not shown). Therefore, we consider NF- $\kappa \mathrm{B}$ to be a key mediator of increased tumor chemoresistance. NF- $\mathrm{kB}$ is a protein complex composed of multiple subunits, including p50, p52, RalA (p65), RalB and c-Rel. It is retained in an inactive form in the cytoplasm by its interaction with IKB $(4,12)$. Extrinsic stimuli such as TNF $\alpha$ cause phosphorylation of I $\kappa \mathrm{B}$ and its subsequent ubiquitination and degradation by the proteasome. This releases NF- $\kappa \mathrm{B}$, which translocates to the nucleus (7). 
A

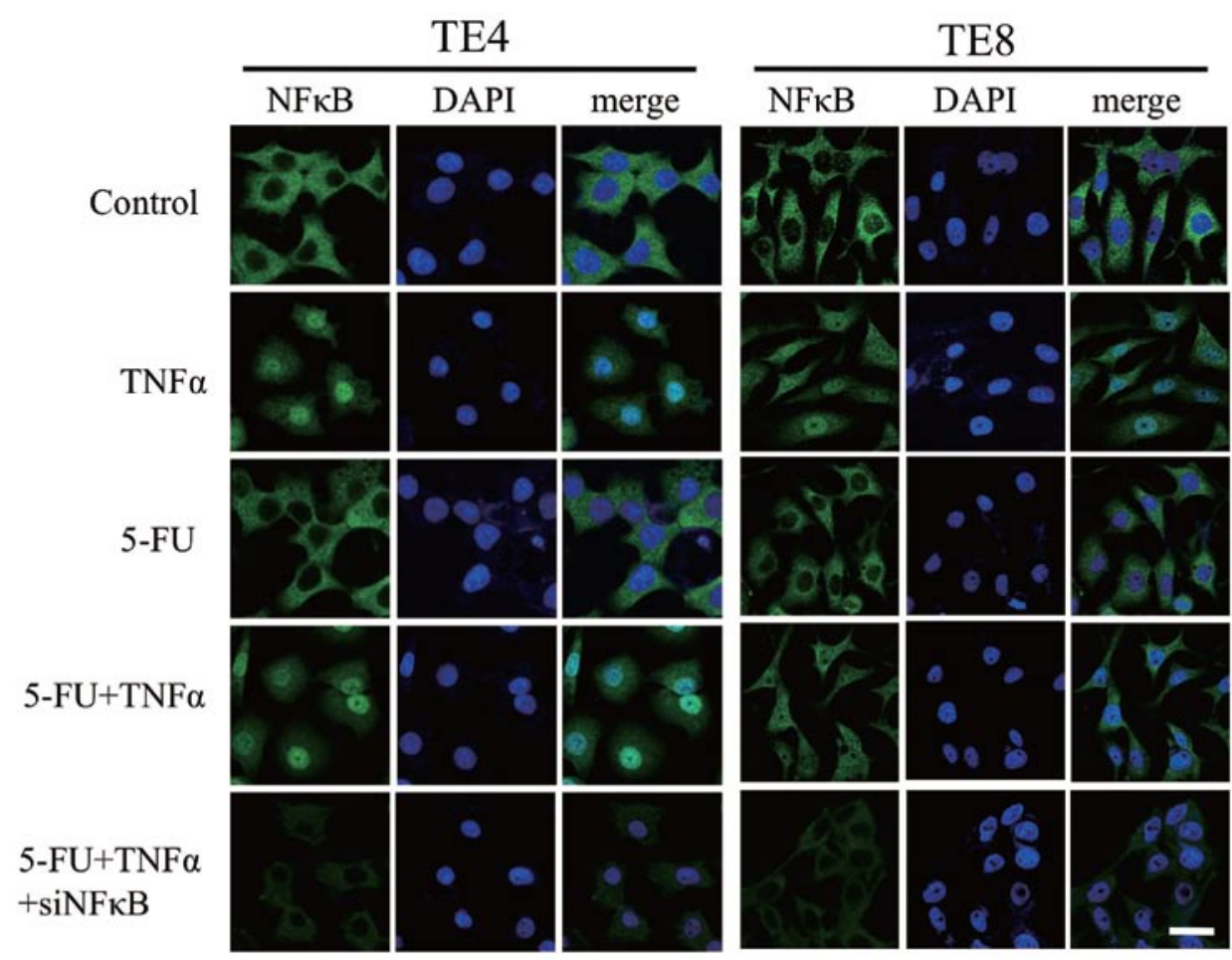

B

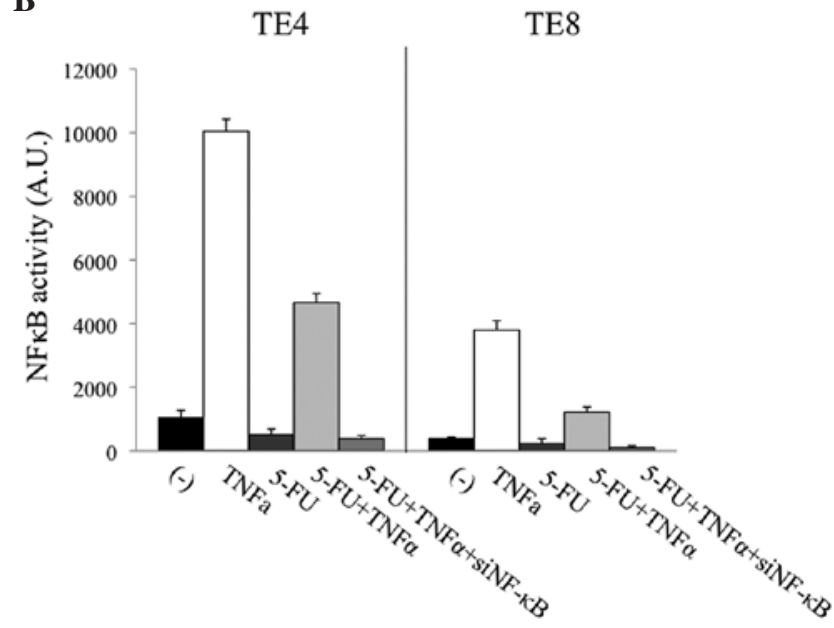

C

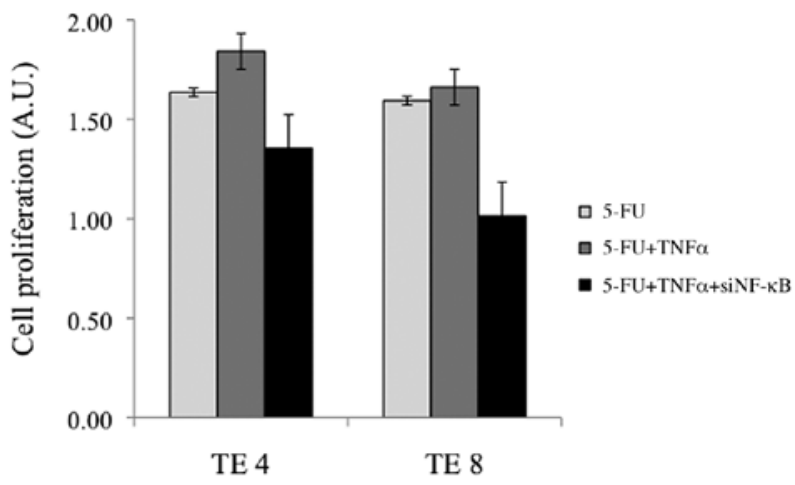

Figure 4. (A) Cells treated with 5-FU, TNF $\alpha$ and NF- $\mathrm{KB}$ siRNA. TNF $\alpha$ induced NF- $\mathrm{KB}$ to translocate to the nucleus. 5-FU slightly decreased the level of NF- $\kappa B$ in cells treated with TNF $\alpha$. A combination of 5-FU and TNF- $\alpha$ significantly decreased the levels of NF- $\kappa B$ in the cytoplasm and nucleus. (B) NF- $\kappa B$ activity in TE4 and TE8 cells was measured by luciferase assays. (C) Proliferation of TE4 and TE8 cells treated with 5-FU, TNFa and NF-kB siRNA.

Several lines of evidence show that constitutive activation of $\mathrm{NF}-\kappa \mathrm{B}$ induces expression of anti-apoptotic genes and drug resistance in cancer cells $(7,12)$. Therefore, many strategies and compounds have recently been developed to target this pathway, including I $\mathrm{B}$ kinase inhibitors, proteasome inhibitors, acetylation inhibitors, gene transfer of antisense RNA and siRNA to inhibit proteins, anti-inflammatory agents and chemoprevention agents (9-11,13-18). However, whether the manipulation of $\mathrm{NF}-\kappa \mathrm{B}$ activation is clinically significant remains unclear.

In this study, we showed that siRNA-mediated suppression of $\mathrm{NF}-\kappa \mathrm{B}$ protein expression in cultured ESCCs resulted in an enhancement of the anti-proliferative effect of 5-FU. Li et al demonstrated that 5-FU or docetaxel induced $\mathrm{NF}-\kappa \mathrm{B}$ activation in human esophageal cancer cells, and pretreatment with an adenoviral-delivered IкB suppressor followed by 5-FU or docetaxel significantly increased apoptosis (11).

Our present findings do not contradict these results, as high concentrations of 5-FU certainly inhibit both cell proliferation and $N F-\kappa B$ activation, and inhibition of $N F-\kappa B$ augments chemotherapeutic effects.

$\mathrm{TNF} \alpha$ is a pro-inflammatory cytokine that regulates cell proliferation, differentiation and apoptosis. One of the most important downstream signaling targets activated by $\mathrm{TNF} \alpha$ is $\mathrm{NF}-\kappa \mathrm{B}(19-21)$. TNF $\alpha$ was found to be strongly expressed in an esophageal carcinoma cell line (22), and TNF $\alpha$ may have a critical role in ESCC. Immunostaining showed expression of $\mathrm{NF}-\kappa \mathrm{B}$ in cultured ESCCs to be almost entirely located in 
the cytoplasm, whereas that in resected ESCC specimens was in the nucleus (data not shown). When cultured ESCCs were exposed to $\mathrm{TNF} \alpha, \mathrm{NF}-\kappa \mathrm{B}$ translocated to the nucleus, and the activity of $\mathrm{NF}-\kappa \mathrm{B}$ increased. Esophageal cancer cells may be affected by cytokines such as TNF $\alpha$ or interleukin- 6 from inflammatory cells in the body. 5-FU had a smaller effect on ESCCs that had elevated levels of TNF $\alpha$-activated NF- $\mathrm{NB}$. Combination therapy of 5-FU and NF- $\mathrm{BB}$ siRNA was effective in ESCCs, providing further evidence that NF- $\kappa \mathrm{B}$ is associated with the sensitivity of 5-FU.

A gene expression profiling study previously identified high expression levels of key regulatory genes in the $N F-\kappa B$ pathway, including TRAF2, an inhibitor of $\mathrm{NF}-\kappa \mathrm{B}$ kinase, and RalB in chemoresistant cancer (12). Moreover, curcumin inhibited $\mathrm{NF}-\kappa \mathrm{B}$ activity and sensitized cancer cells to antiproliferative agents, such as 5-FU or cisplatin (23). Our findings support further investigation of anti-NF- $\kappa \mathrm{B}$ strategies for the treatment of ESCC. Indeed, NF- $\kappa \mathrm{B}$ siRNA therapy may act cooperatively with chemotherapeutic agents. Moreover, NF- $\kappa \mathrm{B}$ inhibition may lower the effective therapeutic dose of 5-FU or of other antitumor agents, such that combination therapy may be a more effective treatment option for ESCCs than chemotherapy alone. The effect of NF- $\mathrm{NB}$ siRNA may be more direct than that of inhibiting TNF $\alpha$. Furthermore, since $\mathrm{NF}-\kappa \mathrm{B}$ is overexpressed in many types of human cancer but present at only very low levels in normal tissues (24), inhibition of $\mathrm{NF}-\kappa \mathrm{B}$ should have minimal side effects on normal tissues.

In conclusion, we demonstrated that $\mathrm{NF}-\kappa \mathrm{B}$ activity was strongly inhibited by $\mathrm{NF}-\kappa \mathrm{B}$ siRNA, resulting in suppression of ESCC proliferation. The effect of 5-FU on ESCCs was decreased by TNF $\alpha$ treatment, while the effect of 5-FU was significantly enhanced when combined with NF- $\kappa \mathrm{B}$ siRNA. Combination therapy of 5-FU and NF- $\kappa \mathrm{B}$ siRNA may provide a new therapeutic option for ESCCs.

\section{Acknowledgements}

This study is supported by grants from the Japan Society for the Promotion of Science.

\section{References}

1. Hokamura N: Surgery and chemoradiation in the treatment of esophageal cancer. Jpn Cancer Clin 55: 7-13, 2009.

2. Pinedo HM and Peters GJ: Fluorouracil: biochemistry and pharmacology. J Clin Oncol 6: 1653-1664, 1988.

3. Irene VB, Godefridus JP, Olaf HT, Masakazu F and Frank AK: Differential activation of cell death and autophagy results in an increased cytotoxic potential for trifluorothymidine compared to 5-fluorouracil in colon cancer cells. Int J Cancer 126: 2457-2468, 2009.

4. Karin M, Cao Y, Greten FR and Li ZW: NF- $\kappa B$ in cancer: from innocent bystander to major culprit. Nat Rev Cancer 2: 301-310, 2002.

5. Karin M: Nuclear factor- $\kappa \mathrm{B}$ in cancer development and progression. Nature 441: 431-436, 2006

6. Li B, Cheung PY, Wang X, Taso SW, Ling MT, Wong YC and Cheung AL: Id-1 activation of PI3K/Akt/NF- $\mathrm{BB}$ signaling pathway and its significance in promoting survival of esophageal cancer cells. Carcinogenesis 28: 2313-2320, 2007.

7. Matthew SH and Sankar G: Signaling to NF-кB. Genes Dev 18: 2195-2224, 2004.
8. Izzo JG, Correa AM, Wu TT, Malhotra U, Chao CK, Luthra R, Ensor J, Dekovich A, Liao Z, Hittelman WN, Aggarwal BB and Ajani JA: Pretherapy nuclear factor- $\kappa \mathrm{B}$ status, chemoradiation resistance, and metastatic progression in esophageal carcinoma. Mol Cancer Ther 5: 2844-2850, 2006.

9. Inoue M, Matsumoto S, Saito H, Tsujitani S and Ikeguchi M: Intraperitoneal administration of a small interfering RNA targeting nuclear factor-kappa B with paclitaxel successfully prolongs the survival of xenograft models mice with peritoneal metastasis of gastric cancer. Int J Cancer 123: 2696-2701, 2008.

10. Tian F, Zang WD, Hou WH, Liu HT and Xue LX: Nuclear factor- $\kappa \mathrm{B}$ signaling pathway constitutively activated in esophageal squamous cell carcinoma cell lines inhibition of growth of cells by small interfering RNA. Acta Biochim Biophys Sin 38: 318-326, 2006.

11. Li J, Minnich DJ, Camp ER, Brank A, Mackay SL and Hochwald SN: Enhanced sensitivity to chemotherapy in esophageal cancer through inhibition of NF-kB. J Surg Res 132: 112-120, 2006

12. Izzo JG, Malhotra U, Wu TT, Ensor J, Luthra R, Lee JH, Swisher SG, Liao Z, Chao KS, Hittelman WN, Aggarwal BB and Ajani JA: Association of activated transcription factor nuclear factor $\kappa \mathrm{B}$ with chemoradiation resistance and poor outcome in esophageal carcinoma. J Clin Oncol 24: 748-754, 2006.

13. Layzer JM, McCaffry AP, Tanner AK, Huang Z, Kay MA and Sullenger BA: In vivo activity of nuclease-resistant siRNAs. RNA 107: 66-71, 2004.

14. Hassani Z, Lemkine GF, Erbacherb P, Palmier K, Alfama G, Giovannangeli C, Behr JP and Demeneix BA: Lipid-mediated siRNA delivery down-regulates exogenous gene expression in the mouse brain at picomolar levels. J Gene Med 7: 198-207, 2005.

15. Nogawa M, Yuasa T, Kimura S, Tanaka M, Kuroda J, Sato K, Yokota A, Toda Y, Kageyama S, Toshiki T, Okada Y and Maekawa T: Intravesical administration of small interfering RNA targeting PLK-1 successfully prevents the growth of bladder cancer. J Clin Invest 115: 978-985, 2005.

16. Liang Z, Yoon Y, Votaw J, Goodman MM, Williams L and Shim H: Silencing of CXCR4 blocks breast cancer metastasis. Cancer Res 65: 967-971, 2005.

17. Mabuchi S, Ohmichi M, Nishio Y, Hayasaka T, Kimura A, Ohta T, Saito M, Kawagoe J, Takahashi K, Yada-Hashimoto N, Sakata M, Motoyama T, Kurachi H, Tasaka K and Murata Y: Inhibition of NF- $\mathrm{B}$ increases the efficacy of cisplatin in in vitro and in vivo ovarian cancer models. J Biol Chem 279: 23477-23485, 2004.

18. Wang W, McLedod HL and Cassidy J: Disulfiram-mediated inhibition of NF-kappaB activity enhances cytotoxicity of 5 -flurouracil in human colorectal cancer cell lines. Int J Cancer 104: 504-511, 2003.

19. Hongxiu L and Xin L: Positive and negative signaling components involved in $\mathrm{TNF} \alpha$-induced $\mathrm{NF}-\kappa \mathrm{B}$ activation. Cytokine 41: 1-8, 2008.

20. Kristin D, Jaclyn M, Lance KH and Fazlul HS: Critical need for clinical trials: an example of a pilot human intervention trial of a mixture of natural agents protecting lymphocytes against TNF- $\alpha$ induced activation of NF- $\mathrm{kB}$. Pharm Res 27: 1061-1065, 2010.

21. Sarkar FH, Li Y, Wang Z and Kong D: NF-kappaB signaling pathway and its therapeutic implications in human diseases. Int Rev Immunol 27: 293-319, 2008.

22. Changhui M, Tianzhong M, Zhongjing S, Ling C, Ning W, Ningxia Z, Xiancai C and Habin C: Silencing of tumor necrosis factor receptor 1 by siRNA in EC109 cells affects cell proliferation and apoptosis. J Biomed Biotechnol 2009: 760540, 2009.

23. Hartojo W, Silvers AL, Thomas DG, Seder CW, Lin L, Rao H, Wang Z, Greenson JK, Giordano TJ, Orringer MB, Rehemtulla A, Bhojani MS, Beer DG and Chang AC: Curcumin promotes apoptosis, increases chemosensitivity, and inhibits nuclear factor kappaB in esophageal adenocarcinoma. Transl Oncol 3: 99-108, 2010.

24. Abdel-Latif MM, O'Riordan JM, Ravi N, Kelleher D and Reynolds JV: Activated nuclear factor-kappa B and cytokine profiles in the esophagus parallel tumor regression following neoadjuvant chemoradiotherapy. Dis Esophagus 18: 246-252, 2005. 